\title{
Quantifying the temporal variation of the contribution of fine sediment sources to sediment yields from Chilean forested catchments during harvesting operations
}

\author{
Cuantificación de la variación temporal de la contribución de fuentes de sedimentos finos \\ a la carga de sedimentos desde cuencas forestadas en Chile durante operaciones de cosecha
}

\author{
Paulina Schuller a, Desmond E Walling b, Andrés Iroumé c*, \\ César Quilodrán ${ }^{d}$, Alejandra Castillo ${ }^{\text {a }}$ \\ ${ }^{a}$ Universidad Austral de Chile, Facultad de Ciencias, Instituto de Ciencias Químicas, Valdivia, Chile. \\ ${ }^{\mathrm{b}}$ University of Exeter, Department of Geography, College of Life and Environmental Sciences, Exeter, UK. \\ *Corresponding author: ${ }^{c}$ Universidad Austral de Chile, Facultad de Ciencias Forestales y Recursos Naturales, \\ Instituto de Conservación, Biodiversidad y Territorio, Valdivia, Chile, tel.: +56-63-2293003, airoume@uach.cl \\ ${ }^{\mathrm{d}}$ Imperial College London, Department of Physics, Space and Atmospheric Physics group, London, UK.
}

\begin{abstract}
SUMMARY
Fingerprinting techniques were incorporated into a paired catchment investigation in southern Chile to quantify the contribution of three fine sediment sources (catchment surfaces, forest roads and stream channels) to catchment suspended sediment yields during forest harvesting and replanting operations. Optimum composite fingerprints for use in sediment source discrimination and apportionment comprised ${ }^{137} \mathrm{Cs}$ and ${ }^{210} \mathrm{~Pb}_{\text {ex }}$ for the control catchment (LUC) throughout the study and for the treatment catchment (LUT) during the pre-harvest period, and ${ }^{137} \mathrm{Cs}$ and soil organic matter during harvest and post-harvest periods for LUT. Prior to harvesting, the dominant sediment source to the sediment load in both catchments was the stream channel and remained relatively constant throughout the study for LUC. For the entire study period the total suspended sediment yield from LUT $\left(3,160 \mathrm{~kg} \mathrm{ha}^{-1}\right)$ approximately doubled that from LUC $\left(1,650 \mathrm{~kg} \mathrm{ha}^{-1}\right)$. Most of this difference is accounted for by the increase in sediment output during the rainy months following clearcutting. The disturbance associated with forest operations in LUT caused the contributions to the load from the catchment slopes and forest roads to increase markedly (total contributions 835 and $795 \mathrm{~kg} \mathrm{ha}^{-1}$, respectively). However, the total contribution from the stream channel for LUT during the study period $\left(1,530 \mathrm{~kg} \mathrm{ha}^{-1}\right)$ remained similar to that from LUC. The results of the investigation demonstrated that any attempt to reduce sediment loading from forest harvesting would require adopting best management practices to reduce sediment mobilization from catchment surfaces and forest roads.
\end{abstract}

Key words: sediment source contribution, forest operations, source fingerprinting, paired catchments, southern Chile.

\section{RESUMEN}

Técnicas de trazadores fueron incorporadas a una investigación de cuencas pareadas en el sur de Chile para cuantificar la contribución de tres fuentes de sedimentos finos (superficie de las cuencas, caminos forestales y cauces) a la carga total de sedimentos en suspensión durante las operaciones de cosecha y reforestación. La composición óptima de trazadores para discriminar y calcular la participación de cada fuente de sedimentos comprendió ${ }^{137} \mathrm{Cs} \mathrm{y}{ }^{210} \mathrm{~Pb}_{\mathrm{ex}}$ para la cuenca control (LUC) durante todo el estudio y para la cuenca de tratamiento (LUT) durante el período previo a la cosecha, y ${ }^{137} \mathrm{Cs}$ y la materia orgánica del suelo durante los períodos de cosecha y post-cosecha para LUT. Antes de la cosecha, la fuente dominante de sedimentos a la carga total de sedimentos en ambas cuencas fue la red de drenaje, y permaneció relativamente constante a lo largo del estudio para LUC. Durante el periodo estudiado, la carga total de sedimentos desde LUT (3.160 $\left.\mathrm{kg} \mathrm{ha}^{-1}\right)$ fue aproximadamente el doble que desde LUC (1.650 kg ha-1). Gran parte de esta diferencia se explica por el aumento de la carga de sedimentos durante los meses lluviosos luego de la cosecha. La alteración por las operaciones forestales en LUT generó que las contribuciones desde las laderas y los caminos forestales aumentaran considerablemente (contribuciones totales de 835 and $795 \mathrm{~kg} \mathrm{ha}^{-1}$, respectivamente). Sin embargo, la contribución total desde el cauce para LUT durante el periodo estudiado ( $\left.1.530 \mathrm{~kg} \mathrm{ha}^{-1}\right)$ permaneció similar a la de LUC. Los resultados de esta investigación demostraron que todo intento para reducir el impacto de las operaciones forestales en las cargas de sedimentos en cuencas en el área de estudio deben focalizarse en adoptar buenas prácticas de manejo para reducir la movilización de sedimentos desde las laderas y los caminos forestales.

Palabras clave: contribución de fuentes de sedimentos, operaciones forestales, trazadores, cuencas pareadas, sur de Chile. 


\section{INTRODUCTION}

Increased sediment mobilization and delivery to streams associated with forest logging change the physicochemical and biological properties of adjacent aquatic ecosystems (Buttle 2011). Studies from around the world aimed at establishing the magnitude of the increase in suspended sediment yield after forest harvesting have mainly been based on traditional catchment experiments (Buttle 2011). Bathurst and Iroumé (2014), using existing data sets, conclude that maximum post-logging sediment yields are up to an order of magnitude higher than those associated with pre-logging periods. However, Buttle (2011) comments that harvesting alone might not substantially contribute to increased sediment fluxes, and Sidle et al. (2004) indicate that the primary sediment sources commonly consist of logging roads, road crossings and skidder trails, rather than the catchment surface. Differences in the quantification of post-logging effects for the different studies arise because many factors influence sediment mobilization, including logging practices, the level of connectivity between the harvested area and the stream network, the quantity, type and management of forest residues, the width of protected riparian areas and several other site characteristics (Gayoso 2015). Although numerous experimental catchment studies have been undertaken to assess the effects of forest logging on sediment yields, to date, few have explicitly established the source of the sediment contributing to the increased flux. The development of sediment source fingerprinting or tracing techniques has provided new opportunities to obtain such information, representing a direct means of establishing and apportioning the source of fine sediment transported by a stream. It involves assembling information on the physical and chemical properties of fine sediment collected at the outlet of a catchment and comparing these properties with those of potential sources (Walling 2005, Collins et al. 2017, Rachels et al. 2020). The success of this approach depends heavily on the selection of several sediment properties, which can clearly discriminate among the potential sources and thereby establish their contribution to the downstream sediment flux. A wide range of sediment properties have been used for this purpose, including major and minor elements (Walling 2005, Collins et al. 2017, Rachels et al. 2020), radionuclides (Matisoff et al. 2002, Walling 2005, Schuller et al. 2013), stable isotopes (Douglas et al. 2003) and isotopes associated with the organic fraction of the sediment (Bravo-Linares et al. 2018). Selection of the best fingerprint properties exercise commonly involves the use of statistical techniques to assess the ability of individual properties to discriminate potential sources and a mixing or unmixing model to estimate the relative contribution of these sources.

The objective of this investigation undertaken in southern Chile is to assess the impact of forestry operations on sediment yields, through the innovative use of fallout radionuclides as sediment source fingerprints to inform on the apportionment of sediment sources. The hypothesis is that in regions in the Southern Hemisphere characterized with frequent atmospheric washout, the deposit of anthropogenic and geogenic fallout radionuclides can provide optimal concentrations to be implemented as fingerprints to investigate the temporal variation of both relative and total source contributions to the total fine sediment catchment outputs. This investigation builds upon Schuller et al. (2013), extending the observation period and investigating the temporal variation of both relative and total source contributions to the total fine sediment output in a forest paired catchment study. Results provide important information to support the implementation of cost-effective control measures.

\section{METHODS}

Study catchments. A paired catchment investigation was undertaken in the coastal mountains of southern Chile (figure $1 \mathrm{~A}$ ). The two catchments, located $1 \mathrm{~km}$ apart, were designated Los Ulmos control (LUC) and Los Ulmos treatment (LUT). Soils were red clayed originating from old volcanic ashes deposited on the coastal metamorphic complex (Iroumé et al. 2006). Further details concerning the characteristics of these catchments and forest covers are provided by Schuller et al. (2013) and summarized in table 1. Suspended sediment monitoring for both catchments covered $\sim 27$ months, extending from 01.10.2009 to 12.12.2011 for LUC, and from 10.09.2009 to 12.12.2011 for LUT. The calibration period extended 6 months between 01.10.2009 and 01.04.2010. Clearcutting operations in LUT comprised $\sim 84 \%$ of the catchment area (100\% of the Eucalyptus nitens plantation); the remaining surface corresponds to riparian native vegetation (13.4\%) and unpaved dirt roads $(2.6 \%)$. Trees were hand-felled with chainsaw and logged to landings located outside the catchment using rubber-tyred skidders. Mean and maximum yarding distances were 66 and $170 \mathrm{~m}$ respectively, and skid trails were created by yarding. Clearcutting occurred between 01 and 15.04.2010 (table 1) shortly before the MayAugust rainy season. Over the past 50 years, this period has typically accounted for $c a .60 \%$ of the total annual rainfall for the study area. During the harvest period, no sediment control measures were implemented. The adoption of best management practices is not compulsory in the country, except for maintaining in place the riparian vegetation along the drainage network. LUT was replanted with E. nitens during the spring (October) of 2011 (table 1). The LUC catchment was not disturbed during the study.

Monitoring of precipitation, discharge and suspended sediment. Continuous rainfall records were generated using two Hobo tipping bucket gauges with resolution of 0.257 $\mathrm{mm}$ located halfway between the catchments. Streamflow was measured using Thompson-type V-notch weirs equipped with data loggers to record water stage at $3 \mathrm{~min}$ in- 


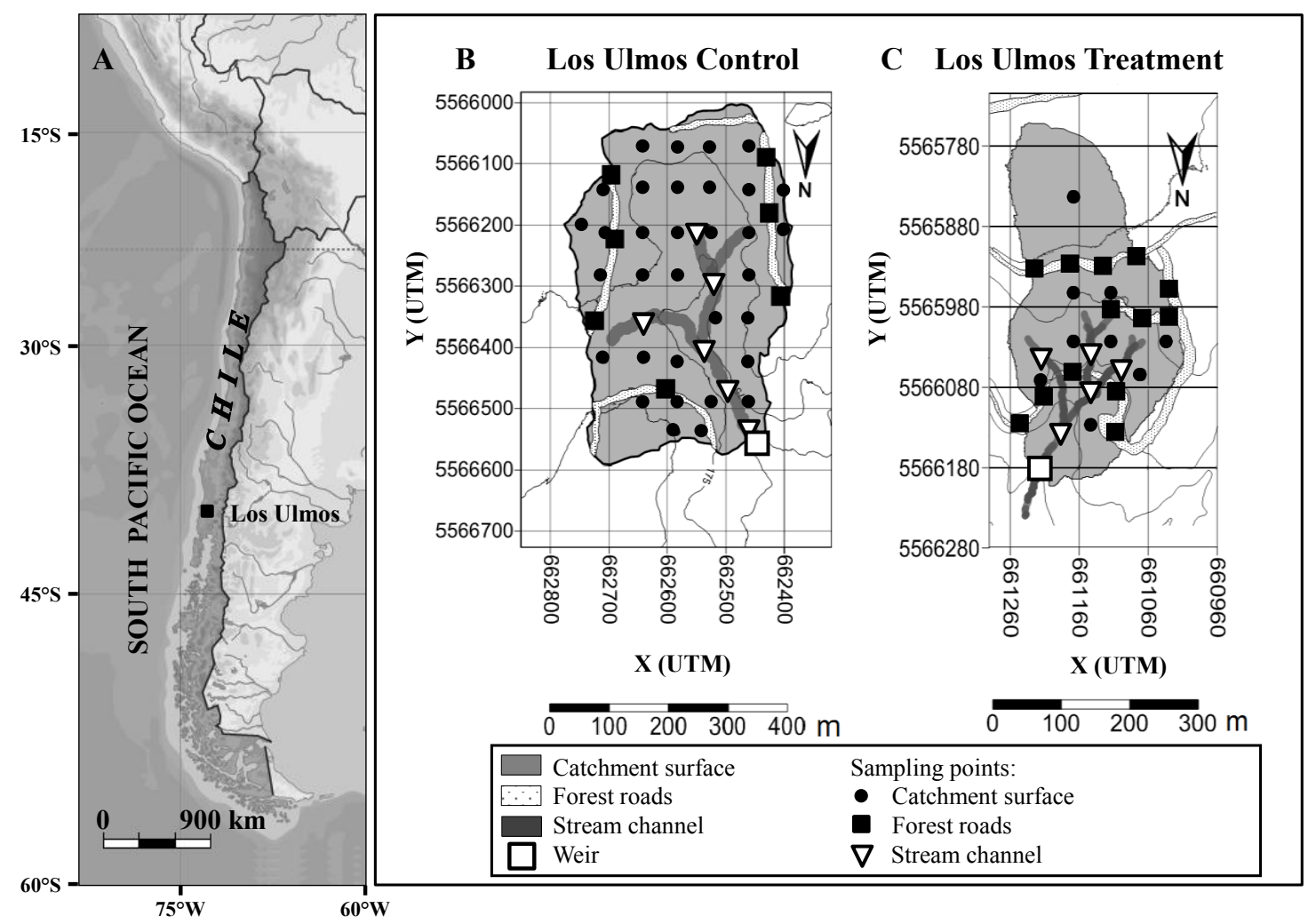

Figure 1. A) Location of the study site within Chile; B) and C) the two catchments and the distribution of sampling points within the catchments.

A) Localización del estudio en Chile; B) y C) las dos cuencas y la distribución de los puntos de muestreo dentro de cada una de ellas.

Table 1. Characteristics of the study catchments and the timing of the forestry operations and the sampling campaigns undertaken to characterize the potential sediment sources.

Las características de las cuencas estudiadas y los periodos de las operaciones forestales y de las campañas de muestreo realizadas para caracterizar las potenciales fuentes de sedimentos.

\begin{tabular}{|c|c|c|}
\hline Catchment & LUC & LUT \\
\hline Latitude; longitude & $40^{\circ} 02^{\prime} \mathrm{S} ; 7^{\circ} 05^{\prime} \mathrm{W}$ & $40^{\circ} 02^{\prime} \mathrm{S} ; 7^{\circ} 06^{\prime} \mathrm{W}$ \\
\hline \multirow[t]{2}{*}{ Vegetation type } & Eucalyptus nitens (67\%) & Eucalyptus nitens \\
\hline & Pinus radiata $(33 \%)$ & \\
\hline Year of plantation establishment & 2000 & 1997 \\
\hline Mean long-term annual precipitation (mm) & 2500 & 2500 \\
\hline Surface (ha) & 19.8 & 7.6 \\
\hline Mean altitude (masl) & 192 & 198 \\
\hline Mean slope (\%) & 18 & 25 \\
\hline Main observation period (dates) & $01.10 .09-12.12 .11$ & $10.09 .09-12.12 .11$ \\
\hline Main harvest period & & $01-15.04 .10$ \\
\hline Replanting period & & 03-07.10.11 \\
\hline Timing of sources zones sampling campaigns & 13-14.07.09 & \\
\hline Pre-harvest & & 08.07 .09 \\
\hline Post-harvest & & 28-29.07.10 and 03.05.11 \\
\hline
\end{tabular}


tervals with accuracy of $\pm 2 \mathrm{~mm}$. The suspended sediment load was documented at each flow measuring station using a flow proportional water sampling procedure (Huber et al. 2010). Water samples, with a volume proportional to the discharge, were collected every 8 hours using an automatically operated electric pump and added to a bulk sample stored in a tank. Every 7 or 15 days during the winter (wet) and summer (dry) periods, respectively, a representative sample of the water and sediment stored in the tank was collected and filtered to obtain the discharge-weighted mean suspended sediment concentration for the sampling period. The suspended sediment load for each sampling period was calculated as the product of this mean suspended sediment concentration and the mean discharge for the period. The tank was emptied and cleaned in readiness for the collection of the subsequent bulk sample.

Sampling potential suspended sediment sources and the sediment output from the catchments. The three potential suspended sediment sources (catchment surface or forested slopes, forest roads and tracks, and stream channels) and the sampling program for characterizing the fingerprint properties of the potential sources and the sediment output from the catchments were described in Schuller et al. (2013). In both catchments, multiple composite samples of source material were collected from the surface $(0-1 \mathrm{~cm})$ of the potential sources at areas with good connectivity to the streams, to characterize the spatial variability of fingerprint properties associated with the individual sources. The distribution of sampling points is shown in figures $1 \mathrm{~B}$ and $\mathrm{C}$ for LUC and LUT, respectively. Samples representative of the catchment surfaces were collected from areas of the forested (or harvested/replanted) slopes using a grid pattern. Samples from forest roads and stream channels were collected along these features from locations which provided evidence of active erosion and sediment mobilization. In the case of the samples collected from forest roads, these aimed at being representative of material that would be mobilized during storm events and therefore included material from road verges and adjacent cut slopes. Along stream channels, composite samples of surface material were collected from the full vertical extent of bank profiles and the stream bed. The composite source material samples, collected from each sampling location point, typically comprised 1-2 kg of material, providing enough mass for subsequent laboratory analyses. The timing of the sediment source sampling campaigns is summarized in table 1 . The source material sampling was repeated in LUT after the completion of harvesting operations and prior to replanting, to characterize the catchment in its disturbed condition. Composite samples collected from potential sources were analyzed individually to ensure that the results obtained were representative of the spatial variability of the properties of the three potential sources.

Two time-integrating trap samplers were installed in the upper part of each weir pool to collect bulk samples of sus- pended sediment to be used as target samples in the source fingerprinting study (Schuller et al. 2013). The sediment collected by the trap samplers was retrieved at approximately monthly intervals (table 2) and was supplemented by fine sediment collected from the beds of the weir ponds. A summary of the target sediment sampling program in relation to precipitation and measured sediment load for the individual sampling periods is presented in table 2 .

Selection of fingerprint properties. Based on Walling (2005) and Matisoff et al. (2002), attention focused on the use of the fallout radionuclides caesium-137 $\left({ }^{137} \mathrm{Cs}\right.$, halflife $30.2 \mathrm{y})$ and excess lead-210 $\left({ }^{210} \mathrm{~Pb}\right.$ ex , half-life $\left.22.2 \mathrm{y}\right)$ as fingerprints. The presence in surface soil of anthropogenic ${ }^{137} \mathrm{Cs}$ in the studied area predominantly reflects global fallout from the atmospheric testing of thermonuclear weapons from 1952 to the mid-1980s. In contrast, the fallout of geogenic ${ }^{210} \mathrm{~Pb}_{\mathrm{ex}}$ can be viewed essentially continuous over time at a specific site (Appleby and Oldfield 1978). Fallouts ${ }^{137} \mathrm{Cs}$ and ${ }^{210} \mathrm{~Pb}_{\text {ex }}$ are strongly and rapidly adsorbed by exchange sites in the surface soil (He and Walling 1996). In undisturbed soils, such as some forest soils, the occurrence of ${ }^{137} \mathrm{Cs}$ and ${ }^{210} \mathrm{~Pb}$ ex is typically characterized by an exponential depth distribution due to their fallout origin and limited post-fallout downward movement in soil. The maximum ${ }^{137} \mathrm{Cs}$ concentration is commonly found slightly below the surface in undisturbed soil, because of the cessation of significant fallout in the 1980s and the very slow downward migration of the peak activity (Schuller et al. 1997, Walling 2013). In the case of ${ }^{210} \mathrm{~Pb}_{\mathrm{ex}}$, , is normally found at the surface, due to the ongoing fallout receipt. Caesium-137 and ${ }^{210} \mathrm{~Pb}_{\mathrm{ex}}$ provide valuable fingerprints for distinguishing surface and subsurface sediment sources. In this study, the catchment surface can be expected to be characterized by significant activities of both radionuclides, whereas forest roads and channel banks are likely to be characterized by lower or zero activities. However, surface sediment can accumulate fresh ${ }^{210} \mathrm{~Pb}_{\mathrm{ex}}$ fallout if it subsequently remains undisturbed for a considerable period. Because of likely contrasts among the organic matter content (SOM) of surface soils, road surfaces and the channel banks (Ritchie et al. 2007), SOM concentration associated with source material samples was included as a possible fingerprint property. The naturally occurring environmental radionuclides potassium- $40\left({ }^{40} \mathrm{~K}\right.$, half-life $\left.1.28 \times 10^{9} \mathrm{y}\right)$ and radium-226 ( ${ }^{226} \mathrm{Ra}$, half-life $\left.1,622 \mathrm{y}\right)$ were also included as possible fingerprints to investigate their potential to discriminate different source materials, because they can be determined by the analytical procedures used for ${ }^{137} \mathrm{Cs}$ and ${ }^{210} \mathrm{~Pb}_{\text {ex }}$.

Measurement of the fingerprint properties of source material and target samples. Since radionuclide activities are grain size dependent (He and Walling 1996, Walling 2005), attention was directed to the $<63 \mu \mathrm{m}$ fraction when determining the fingerprint properties of potential source 
Table 2. The timing of fine sediment collection from catchment outlets and precipitation and sediment load associated with each sampling period for LUC and LUT. The relative contribution of the three sources to the target sediment samples collected from both catchments and the values of relative mean error (RME) for a comparison of estimated and measured fingerprint concentrations in each target sample.

Los períodos de recolección de sedimentos en las salidas de las cuencas, y la precipitación y carga de sedimentos asociados a cada período de muestreo en LUC y LUT. La contribución relativa de las tres fuentes de sedimentos a las muestras objetivo obtenidas en cada cuenca y los valores del error relativo medio (RME) para la comparación de las concentraciones estimadas y medidas de trazadores en cada muestra objetivo.

\begin{tabular}{|c|c|c|c|c|c|c|c|c|c|}
\hline \multirow[t]{3}{*}{ Catchment } & \multirow{3}{*}{$\begin{array}{l}\text { Main } \\
\text { observation } \\
\text { period }\end{array}$} & \multirow{2}{*}{\multicolumn{2}{|c|}{$\begin{array}{l}\text { Sampling period } \\
\text { of the target sediment }\end{array}$}} & \multirow{3}{*}{$\begin{array}{l}\text { Precipitation } \\
(\mathrm{mm})\end{array}$} & \multirow{3}{*}{$\begin{array}{c}\text { Sediment } \\
\text { load }\left(\mathrm{kg} \mathrm{ha}^{-1}\right)\end{array}$} & \multicolumn{3}{|c|}{ Relative contribution to sediment load (\%) } & \multirow{3}{*}{$\begin{array}{l}\text { RME } \\
(\%)\end{array}$} \\
\hline & & & & & & \multirow{2}{*}{$\begin{array}{c}\text { Catchment } \\
\text { surface }\end{array}$} & \multirow{2}{*}{$\begin{array}{l}\text { Forest } \\
\text { roads }\end{array}$} & \multirow{2}{*}{$\begin{array}{l}\text { Stream } \\
\text { channel }\end{array}$} & \\
\hline & & from & to & & & & & & \\
\hline \multirow[t]{21}{*}{ LUC } & & 01.10 .09 & 30.10 .09 & 291 & 155 & $12 \pm 2$ & $1.2 \pm 0.4$ & $87 \pm 2$ & 2.99 \\
\hline & & 30.10 .09 & 03.12 .09 & 177 & 59 & $19 \pm 2$ & $0.6 \pm 0.2$ & $80 \pm 2$ & 6.84 \\
\hline & & 03.12 .09 & 30.12 .09 & 85 & 30 & $29 \pm 2$ & $0.5 \pm 0.3$ & $71 \pm 2$ & 8.38 \\
\hline & & 30.12 .09 & 15.01 .10 & 46 & 31 & $4 \pm 1$ & $1.3 \pm 0.4$ & $95 \pm 1$ & 6.18 \\
\hline & & 15.01 .10 & 09.02 .10 & 127 & 48 & $12 \pm 1$ & $1.0 \pm 0.5$ & $87 \pm 1$ & 7.75 \\
\hline & & 09.02 .10 & 19.03 .10 & 110 & 35 & $8 \pm 2$ & $0.9 \pm 0.4$ & $91 \pm 2$ & 4.38 \\
\hline & & 19.03 .10 & 09.06 .10 & 293 & 75 & $0.6 \pm 0.1$ & $33 \pm 2$ & $67 \pm 2$ & 16.09 \\
\hline & & 09.06 .10 & 29.07 .10 & 622 & 60 & $2.0 \pm 0.7$ & $3.3 \pm 0.9$ & $95 \pm 1$ & 5.11 \\
\hline & & 29.07.10 & 01.09 .10 & 471 & 431 & $4 \pm 1$ & $4 \pm 1$ & $93 \pm 2$ & 2.89 \\
\hline & & 01.09 .10 & 01.10 .10 & 87 & 10 & $4 \pm 1$ & $13 \pm 2$ & $82 \pm 3$ & 1.91 \\
\hline & & 01.10 .10 & 24.11 .10 & 246 & 43 & $3 \pm 1$ & $5 \pm 2$ & $92 \pm 2$ & 2.46 \\
\hline & & 24.11 .10 & 21.12 .10 & 83 & 29 & $0.5 \pm 0.6$ & $20 \pm 3$ & $79 \pm 4$ & 14.03 \\
\hline & & 21.12 .10 & 10.03 .11 & 189 & 75 & $4 \pm 2$ & $24 \pm 3$ & $72 \pm 5$ & 2.03 \\
\hline & & 10.03 .11 & 11.04 .11 & 113 & 22 & $0.5 \pm 0.2$ & $15 \pm 3$ & $85 \pm 3$ & 8.82 \\
\hline & & 11.04 .11 & 20.05 .11 & 266 & 29 & $17 \pm 2$ & $28 \pm 2$ & $55 \pm 2$ & 1.04 \\
\hline & & 20.05 .11 & 20.06 .11 & 282 & 51 & $0.4 \pm 0.2$ & $27 \pm 4$ & $73 \pm 4$ & 18.88 \\
\hline & & 20.06 .11 & 28.07 .11 & 321 & 81 & $0.9 \pm 0.4$ & $12 \pm 2$ & $87 \pm 2$ & 8.61 \\
\hline & & 28.07.11 & 31.08 .11 & 378 & 156 & $15.3 \pm 0.9$ & $8 \pm 1$ & $77 \pm 2$ & 0.68 \\
\hline & & 31.08 .11 & 11.10 .11 & 258 & 180 & $1.3 \pm 0.4$ & $17 \pm 1$ & $82 \pm 2$ & 6.10 \\
\hline & & 11.10 .11 & 15.11 .11 & 50 & 31 & $4.0 \pm 1.0$ & $4 \pm 1$ & $92 \pm 1$ & 3.82 \\
\hline & & 15.11 .11 & 12.12 .11 & 93 & 22 & $9.5 \pm 0.9$ & $11 \pm 1$ & $80 \pm 2$ & 0.58 \\
\hline \multirow[t]{9}{*}{ LUT } & Pre-harvest & 10.09 .09 & 01.10 .09 & 68 & 46 & $3 \pm 1$ & $30 \pm 11$ & $67 \pm 11$ & 2.68 \\
\hline & & 01.10 .09 & 30.10 .09 & 291 & 91 & $8.9 \pm 0.7$ & $7 \pm 4$ & $84 \pm 4$ & 15.95 \\
\hline & & 30.10 .09 & 03.12 .09 & 177 & 54 & $20.5 \pm 0.8$ & $7 \pm 4$ & $72 \pm 4$ & 19.13 \\
\hline & & 03.12 .09 & 30.12 .09 & 85 & 47 & $12.7 \pm 0.5$ & $7 \pm 3$ & $81 \pm 3$ & 20.57 \\
\hline & & 30.12 .09 & 15.01 .10 & 46 & 23 & $9.3 \pm 0.5$ & $10 \pm 5$ & $80 \pm 5$ & 13.11 \\
\hline & & 15.01 .10 & 09.02 .10 & 127 & 26 & $5.0 \pm 0.6$ & $6 \pm 2$ & $89 \pm 2$ & 24.33 \\
\hline & & 09.02 .10 & 19.03 .10 & 110 & 22 & $10.1 \pm 0.6$ & $6 \pm 2$ & $84 \pm 2$ & 18.79 \\
\hline & During harvest & 19.03 .10 & 15.04 .10 & 64 & 20 & $54 \pm 4$ & $25 \pm 2$ & $20 \pm 5$ & 3.27 \\
\hline & Post-harvest & 15.04 .10 & 13.05 .10 & 86 & 600 & $16 \pm 3$ & $1.3 \pm 0.5$ & $82 \pm 2$ & 7.78 \\
\hline
\end{tabular}


Table 2. Continued

\begin{tabular}{ccccccccc}
\hline 13.05 .10 & 09.06 .10 & 143 & 61 & $4.4 \pm 2$ & $1.3 \pm 0.8$ & $94 \pm 2$ & 10.63 \\
& 09.06 .10 & 29.07 .10 & 622 & 393 & $13 \pm 3$ & $29 \pm 2$ & $58 \pm 4$ & 3.03 \\
& 29.07 .10 & 01.09 .10 & 471 & 646 & $42 \pm 5$ & $17 \pm 4$ & $41 \pm 6$ & 1.67 \\
& 01.09 .10 & 01.10 .10 & 87 & 12 & $35 \pm 6$ & $40 \pm 4$ & $25 \pm 8$ & 1.14 \\
& 01.10 .10 & 24.11 .10 & 246 & 70 & $47 \pm 4$ & $25 \pm 3$ & $29 \pm 5$ & 1.81 \\
& 24.11 .10 & 12.01 .11 & 94 & 88 & $78 \pm 2$ & $19 \pm 1$ & $2 \pm 1$ & 9.06 \\
12.01 .11 & 10.03 .11 & 178 & 119 & $42 \pm 1$ & $56 \pm 1$ & $1.7 \pm 0.6$ & 13.01 \\
& 10.03 .11 & 11.04 .11 & 113 & 35 & $46 \pm 1$ & $52.4 \pm 0.9$ & $1.4 \pm 0.7$ & 11.92 \\
& 11.04 .11 & 20.05 .11 & 266 & 48 & $45 \pm 1$ & $52.5 \pm 0.9$ & $2.1 \pm 0.9$ & 10.10 \\
& 20.05 .11 & 20.06 .11 & 282 & 104 & $42 \pm 3$ & $54 \pm 2$ & $4 \pm 2$ & 5.32 \\
& 20.06 .11 & 28.07 .11 & 321 & 56 & $29 \pm 5$ & $3 \pm 1$ & $68 \pm 5$ & 3.47 \\
& 28.07 .11 & 31.08 .11 & 378 & 426 & $20 \pm 3$ & $53 \pm 3$ & $28 \pm 5$ & 0.96 \\
& 31.08 .11 & 11.10 .11 & 258 & 105 & $10 \pm 3$ & $1.4 \pm 0.6$ & $89 \pm 3$ & 14.87 \\
Post-replanting & 11.10 .11 & 15.11 .11 & 50 & 36 & $26 \pm 3$ & $1.1 \pm 0.4$ & $73 \pm 3$ & 13.79 \\
& 15.11 .11 & 12.12 .11 & 93 & 27 & $32 \pm 4$ & $18 \pm 3$ & $50 \pm 5$ & 3.15 \\
\hline
\end{tabular}

materials and the target samples of fine sediment. This facilitated direct comparison of target and source samples and no additional particle size correction was applied (Schuller et al. 2013). Target samples were dewatered by vacuum filtration through MFS ADVANTEC GC 50 glass fiber filters with a $1.2 \mu \mathrm{m}$ pore size. The dewatered fine sediment target samples collected from catchment outlets and all source material samples were air-dried, oven-dried at $40^{\circ} \mathrm{C}$, disaggregated and sieved to $<63 \mu \mathrm{m}$ prior to analysis.

For radionuclide analyses, an aliquot of $c a .80 \mathrm{~g}$ of the $<63 \mu \mathrm{m}$ fraction of each source and target sample was sealed in a Petri dish and stored for at least 3 weeks prior to radiometric assay to ensure equilibrium between ${ }^{226} \mathrm{Ra}$ and its short-lived easily detected gamma emitting daughter ${ }^{214} \mathrm{~Pb}$. The mass activity densities (activities) of ${ }^{137} \mathrm{Cs},{ }^{210} \mathrm{~Pb},{ }^{40} \mathrm{~K}$ and ${ }^{226} \mathrm{Ra}$ were determined by gammaspectrometry, using an ORTEC high-resolution, extended range Ge detector with $53 \%$ relative efficiency, coupled to a PC based digital analyzer system employing ORTEC GammaVision software. The detector was calibrated for the same sample geometry, with standards characterized by a bulk density and grain size like those of the analyzed sample and prepared using certified standard solutions type QCYB400 and type QCYB410 provided by Eckert and Ziegler Nuclitec GmbH. Count times were more than $72,000 \mathrm{~s}$ per sample, providing results with an analytical precision of $c a . \pm 10 \%$ at the $95 \%$ level of confidence. The organic carbon content (SOC) of the $<63 \mu \mathrm{m}$ fraction was measured by organic matter oxidation in a sodium dichromate $\left(\mathrm{Na}_{2} \mathrm{Cr}_{2} \mathrm{O}_{7}\right)$ and sulphuric acid $\left(\mathrm{H}_{2} \mathrm{SO}_{4}\right)$ solu- tion. After $24 \mathrm{~h}$, the chromate reduction was calculated by measuring supernatant absorbance at $600 \mathrm{~nm}$ wavelength with a spectrophotometer. SOM was estimated from SOC content using a Sprengler coefficient of 1.724 .

Source fingerprinting and source ascription. The relative contributions of the potential sediment sources to target samples representative of the total fine sediment load for specific sampling intervals were estimated using a standard sediment source fingerprinting approach described in detail by Schuller et al. (2013). In brief, key components involved, firstly, comparing the fingerprint properties of individual target sediment samples collected at catchment outlets with the equivalent mean values for the properties of the three potential sources to ensure that the former fell within the range of the latter. Only properties which passed this test were used in subsequent analyses. Secondly, the discriminatory power of fingerprint properties was tested statistically by using the non-parametric Kruskal-Wallis $\mathrm{H}$ test, to compare the property values associated with the individual samples collected from the three different potential sources. Only properties which demonstrated a significant difference between the sources were selected. A multiple discriminant function analysis was subsequently employed to select the optimum composite fingerprint set to be used in source apportionment, from those properties identified as possible fingerprints in the first stage. The relative contributions of the potential sources to a target sediment sample were estimated using a multivariate mixing model that was optimized by minimizing an objective function reflecting the difference between the observed 
and predicted property concentrations of sediment (Walling and Collins 2000). The objective function, equation [1], used for the optimization was:

$$
\sum_{i=1}^{n}\left\{\left(C_{i}-\left[\sum_{s=1}^{m} P_{S} S_{s i}\right]\right) / C_{i}\right\}^{2}
$$

where $\mathrm{C}_{\mathrm{i}}$ is the concentration of the fingerprint property $\mathrm{i}$ in the time-integrated suspended sediment sample, $\mathrm{P}_{\mathrm{s}}$ the optimized relative contribution from source $\mathrm{s}, \mathrm{S}_{\mathrm{si}}$ the mean concentration of the fingerprint property $i$ in source $s, n$ the number of fingerprint properties comprising the optimum composite fingerprint and $\mathrm{m}$ the number of sediment sources.

The mixing model assumes that the fingerprint properties are conservative, so that the properties of the suspended sediment directly reflect those of its sources and comprise material only from the identified sources. The result is conditioned by two requirements: $0 \leq P_{s} \leq 1$ and $\sum_{s=1}^{m} P_{s}=1$

The uncertainty introduced by the spatial variability of the properties of a given source and the need to represent this concentration as a single mean value (i.e., $\mathrm{S}_{\mathrm{si}}$ ) in the mixing model was considered by using a Monte Carlo procedure to introduce different possible values of $\mathrm{S}_{\mathrm{s}}$, derived using the standard error of the mean values, into the mixing model. This Monte Carlo procedure involved 50,000 iterations and the resulting estimates of the contribution of individual sources to the target sediment sample were characterized by the mean value and its $95 \%$ confidence limits. Mean contributions were calculated for each target sediment sample and linked to individual sampling periods represented by the time integrated suspended sediment samples.

The goodness of fit provided by the multivariate mixing model was tested by comparing the measured fingerprint property concentrations for target sediment samples with the corresponding values predicted by the optimized mixing model. For this purpose, the relative mean error (RME) for each target sample was calculated using equation [2] and expressed in percentage.

$$
R M E=1 / n\left(\sum_{i=1}^{n}\left|\left(C_{i}-\left[\sum_{s=1}^{m} P_{S} S_{s i}\right]\right) / C_{i}\right|\right)
$$

Estimates of the total mass of sediment contributed by each of the three potential sources during each observation period were obtained by coupling the relative contribution of the three potential sources with information on the total sediment load associated with each sampling period.

\section{RESULTS}

The impact of catchment disturbance on sediment yield. Rainfall and sediment loads documented for LUC and LUT during successive intervals of the overall study are summarized in table 2 . Figure 2 also presents the measured rainfall, runoff and sediment load for LUC and LUT for the successive individual sampling intervals.
The runoff response of both catchments was similar during the entire study period, with no detectable runoff increases in LUT after clearcutting (figures $2 \mathrm{C}, \mathrm{D}$ and $3 \mathrm{~A}$ ). However, the sediment output from LUT (figure 2F) provides clear evidence of increase after forest harvesting, when compared to that from LUC (figure 2E). For the period 01.10.2009 to 19.03.2010, which preceded the commencement of forest harvesting in LUT, the total sediment output from LUT ( $\left.263 \mathrm{~kg} \mathrm{ha}^{-1}\right)$ was slightly less than that from LUC (358 $\left.\mathrm{kg} \mathrm{ha}^{-1}\right)$. The total sediment output from LUT for the 4.5-month wet period (15.04.2010 to 01.09.2010, recorded rainfall of $1,320 \mathrm{~mm}$ ) following the forest harvesting was $1,700 \mathrm{~kg} \mathrm{ha}^{-1}$, whereas the value for the equivalent period for LUC was $538 \mathrm{~kg} \mathrm{ha}^{-1}$, indicating that during these 4.5 -months following forest harvesting the fine sediment output in LUT was more than three times that of LUC.

Considering essentially the same 4.5 -month observation period for the subsequent year (11.04.2011 to $31.08 .2011)$, rainfall $(1,250 \mathrm{~mm})$ was slightly less than that for $2010(1,320 \mathrm{~mm})$, although it was more evenly distributed throughout the rainy season (figures $2 \mathrm{~A}$ and $\mathrm{B}$ ). In 2011, the sediment output from LUC during this period was $316 \mathrm{~kg} \mathrm{ha}^{-1}$ and therefore, as might be expected, less than that for $2010\left(538 \mathrm{~kg} \mathrm{ha}^{-1}\right)$. This difference reflects the lack of periods with very high rainfall totals and the slightly lower rainfall total for 2011. However, the sediment output from LUT (633 $\left.\mathrm{kg} \mathrm{ha}^{-1}\right)$ remained higher than that from LUC, although the increase was reduced to a $c a$. 2-fold. During the two observation periods following replanting (extending from 11.10.2011 to 12.12.2011, table 2), the total sediment yields from LUC and LUT were similar (54 and $63 \mathrm{~kg} \mathrm{ha}^{-1}$, respectively).

Figure 3B presents the cumulative daily sediment load of both catchments. It corroborates the interpretation of the behavior of treatment and control catchments presented above. Considering the overall monitoring period, the sediment output from LUT $\left(\sim 3,160 \mathrm{~kg} \mathrm{ha}^{-1}\right)$ approximately doubled that from LUC $\left(\sim 1,650 \mathrm{~kg} \mathrm{ha}^{-1}\right)$; with this increase being accounted for primarily by the increased sediment yield from LUT during the 4.5 months after harvesting.

Assessment of the discriminatory power of the included fingerprint properties and selection of the optimum composite fingerprints for source apportionment. Application of the non-parametric Kruskal-Wallis test and multiple discriminant function analysis indicated that the optimum composite fingerprint sets for source discrimination and apportionment estimation comprised ${ }^{137} \mathrm{Cs}$ and ${ }^{210} \mathrm{~Pb}$ ex for LUC throughout the study period and for LUT pre-harvest. Caesium-137 and SOM provided the optimum composite fingerprint for LUT during the post-harvest period. Composite fingerprints successfully classified $83.3 \%$ and $82.7 \%$ of the source material samples collected for LUC and LUT pre-harvest, respectively, and $71.9 \%$ of the samples collected from LUT post-harvest. 
Source contributions to the sediment output from the study catchments and their changes through time. The values for the relative contributions of the individual sources summarized in table 2 represent the mean derived from the multiple estimates provided by the Monte Carlo procedure and its $95 \%$ confidence limits. The goodness of fit of the fingerprint property concentrations of the target samples generated by the optimized mixing model to the measured
A

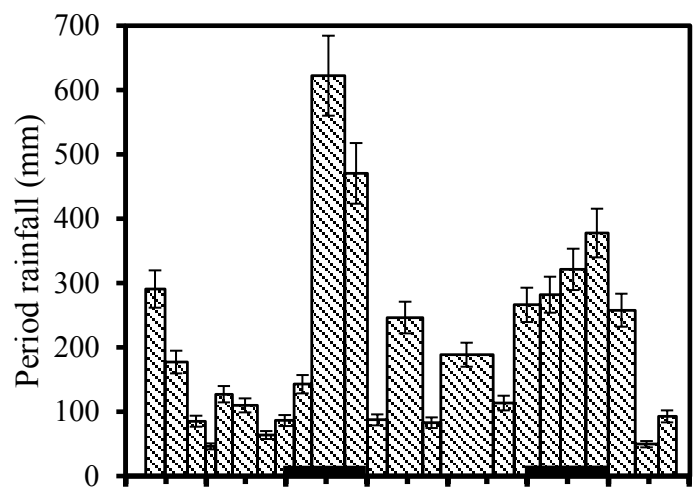

$\mathrm{C}$

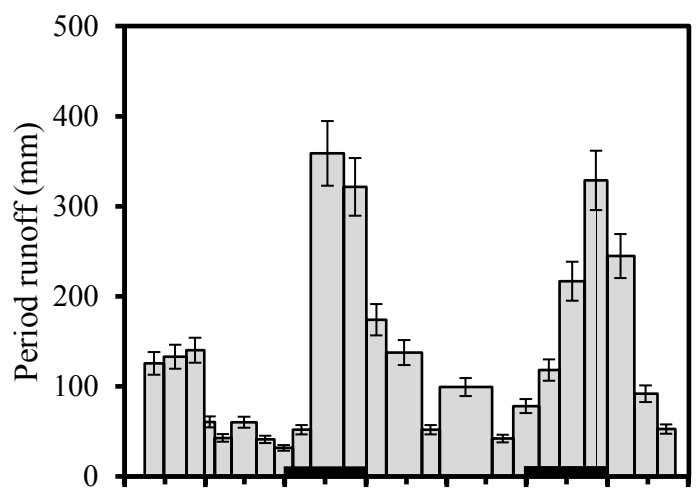

E

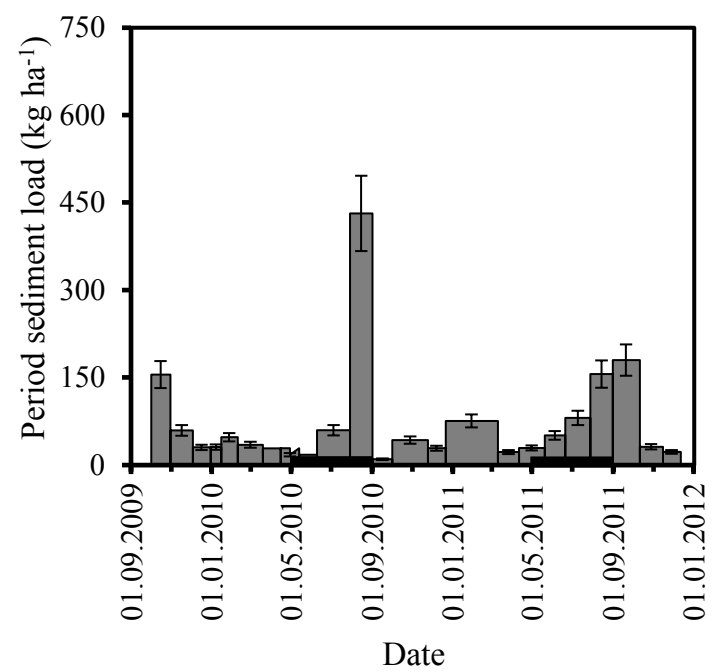

LUT

$\mathrm{B}$

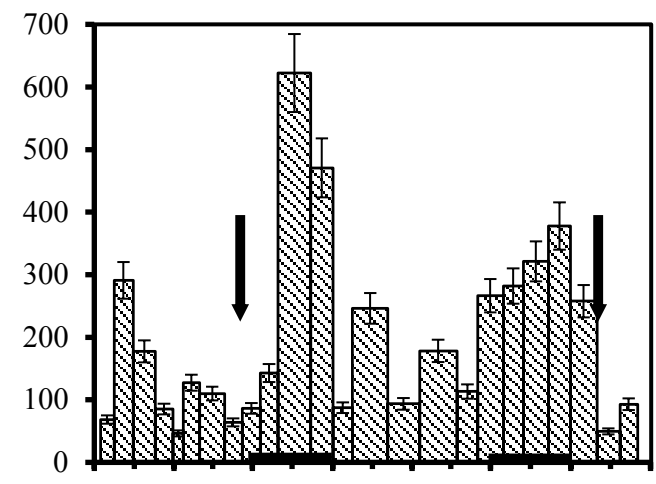

D

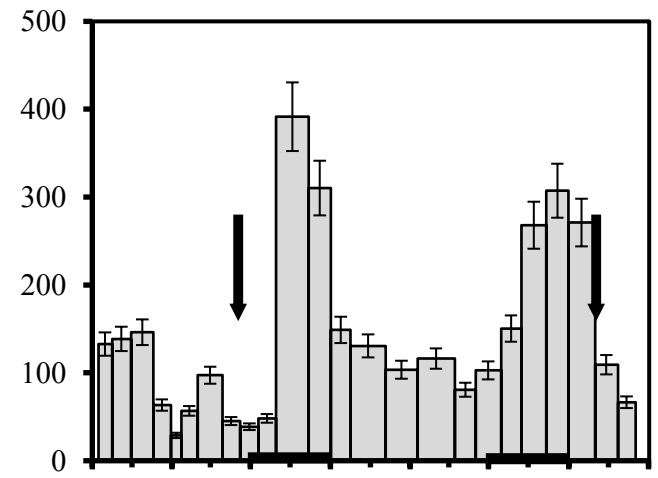

$\mathrm{F}$

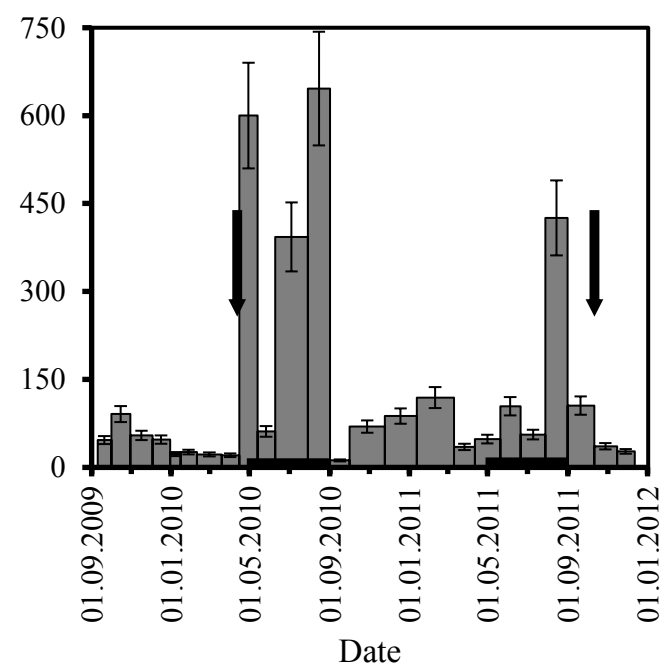

Figure 2. Total precipitation ( $A$ and $B$ ), runoff ( $C$ and $D)$ and sediment load $(E$ and $F$ ) for each successive period between samplings in LUC and LUT, respectively. For the LUT catchment, the vertical arrows represent the dates of completion of forest harvesting and replanting, respectively. The horizontal black lines superimposed on the time axis show the typical timing of the wet season in the study site, based on long-term records.

Precipitación total (A y B), escorrentía (C y D) y carga de sedimentos (E y F) para cada periodo sucesivo entre muestreos en LUC y LUT, respectivamente. Para la cuenca LUT, las flechas verticales a la izquierda y derecha representan las fechas de término de la cosecha y reforestación, respectivamente. Las líneas horizontales en negro superpuestas al eje de tiempo muestran los periodos típicos de la estación lluviosa en el sitio de estudio, basados en registros de largo plazo. 
concentrations in those samples, as indicated by the relative mean error (RME), is also listed for each target sample in table 2 . With a maximum value of $\sim 25 \%$ and $c a$. $85 \%$ of the values $<15 \%$ and $c a$. $66 \%$ of the values $<10 \%$, RME values are considered acceptable.

Relative source contributions. Information on the temporal variation of the relative contributions of the three potential sources to the target samples collected from the two study catchments and their associated loads is presented in table 2 and in figures $4 \mathrm{~A}$ and $\mathrm{B}$. Considering the pre-logging period, both catchments are characterized by similar relative source contributions, with $70-90 \%$ of sediment output co- ming from stream channels. Catchment surface represents the next most important source, contributing $c a .15 \%$ of sediment output. The forest roads represent a minor, but nevertheless significant, sediment source in both catchments, contributing about 10 and $1 \%$ of the sediment output from LUT and LUC, respectively.

Relative source contributions from LUC stay constant during the remainder of the study period, although roads assume superior importance during the wet seasons of both 2010 and 2011. Contribution from roads also increases during the summer of 2010-2011.

In the case of LUT, disturbance of the catchment by clear felling at the beginning of the wet season caused

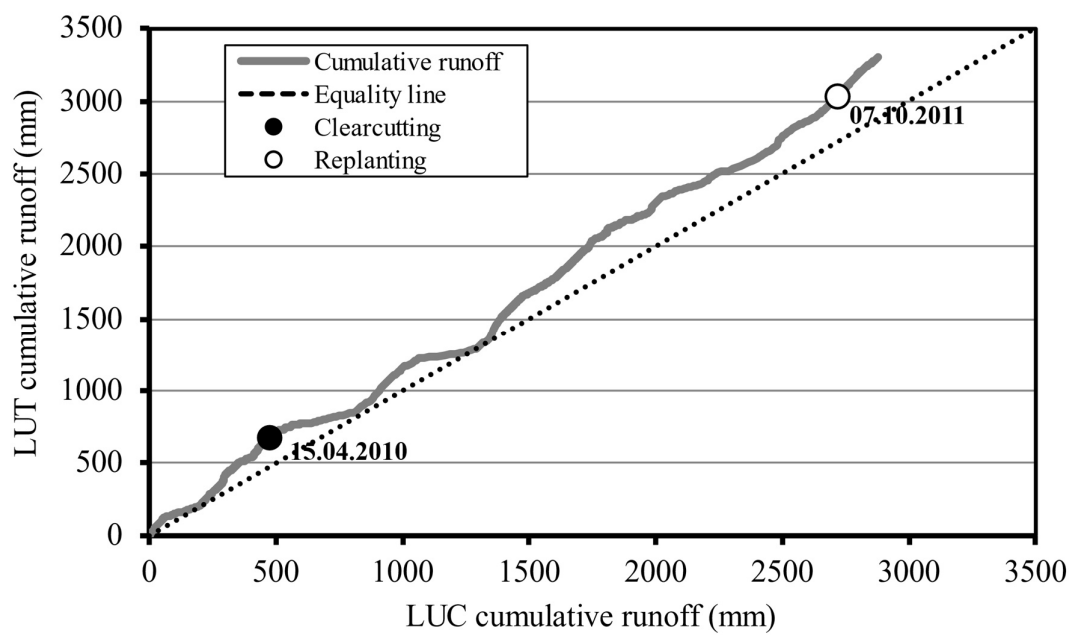

B

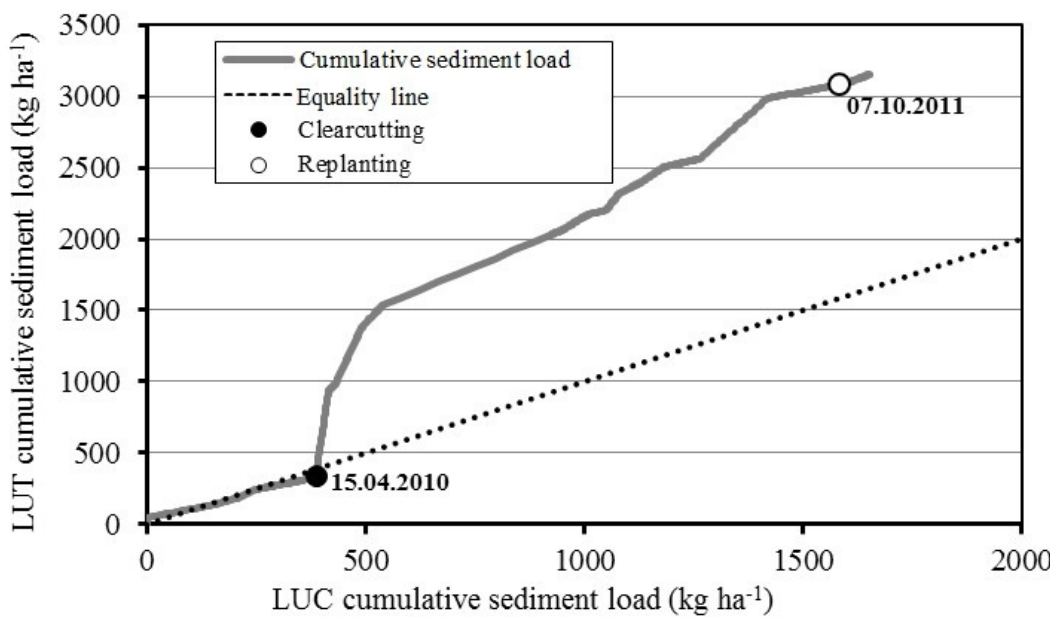

Figure 3. A) Double mass plot of the daily runoff from the two study catchments. B) Double mass plot of the daily fine sediment loads from the two study catchments. The black and white dots represent the dates of completion of harvesting and replanting, respectively, in LUT.

A) Curvas doble másicas de las escorrentías diarias de sedimento fino desde las dos cuencas estudiadas. B) Curvas doble másicas de las cargas diarias de sedimento fino desde las dos cuencas estudiadas. En A) y B), los puntos en negro y blanco representan las fechas del término de la cosecha y reforestación, respectivamente, en LUT. 
major changes in the relative importance of the three sediment sources. During the sampling period from 19.03 to 15.04 .2010 , that included clearcut operations, the relative contribution from the stream channel decreased markedly to $\sim 20 \%$, and the relative contributions from both the catchment surface and forest roads significantly increased from $\sim 15$ to $\sim 55 \%$ and from $\sim 10$ to $\sim 25 \%$, respectively.
During the two months following the completion of clearcutting in LUT (15.04.2010 to 09.06.2010), the importance of the catchment surface and forest roads as sediment sources declined markedly, returning to relative contributions like those associated with the pre-harvest period. Subsequently, during the period extending from 09.06.2010 to 31.08 .2011 , the contributions from both slopes and forest roads again increased and dominated
A

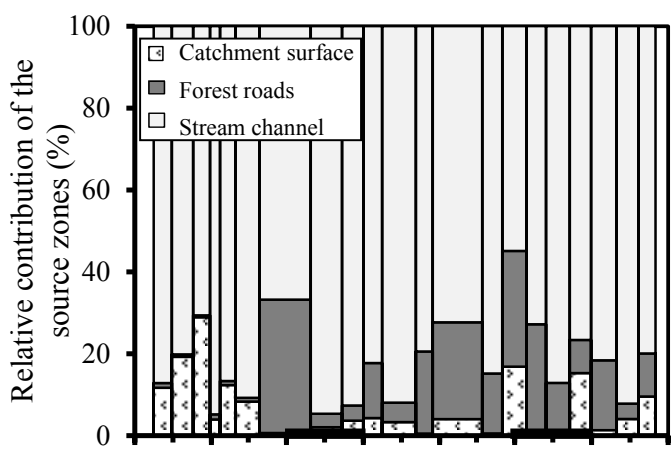

C

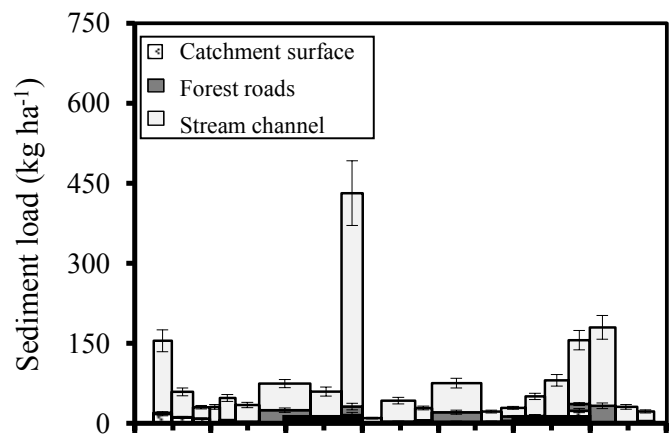

E

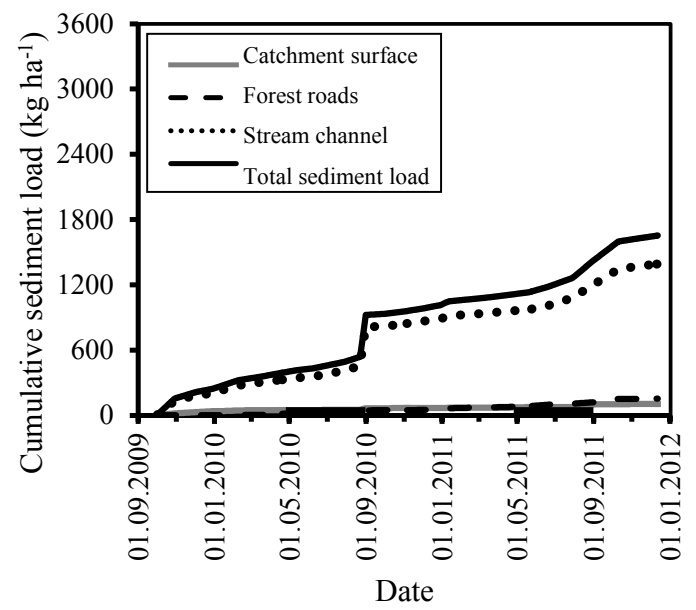

LUT

B

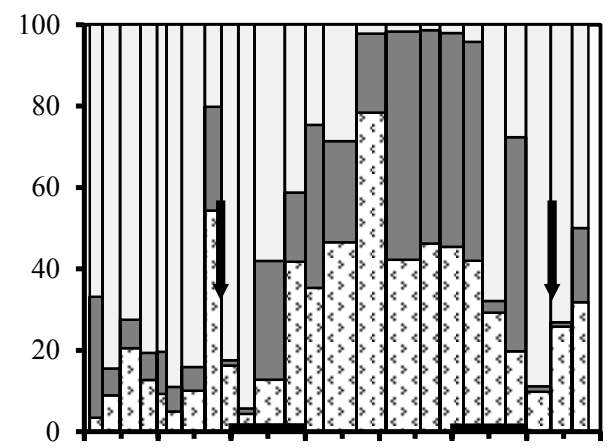

$\mathrm{D}$

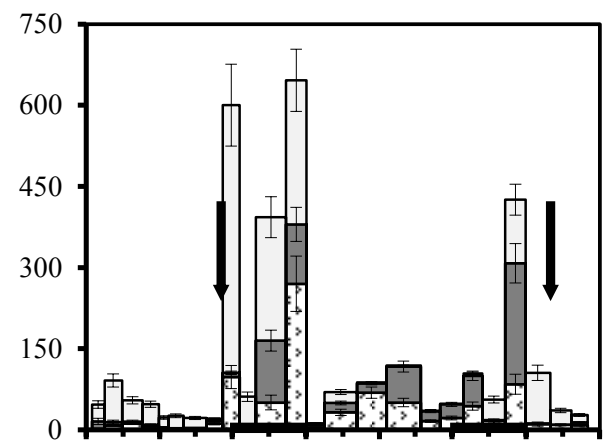

F

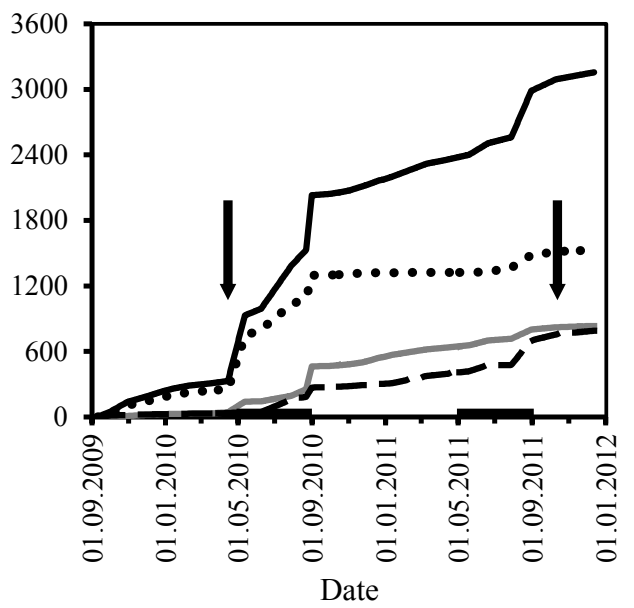

Figure 4. Temporal variation of the relative contribution (A and B), the total magnitude of the contribution (C and D) and the cumulative sediment load ( $\mathrm{E}$ and $\mathrm{F}$ ) from the three potential sources to the time-integrated samples collected at the outlets of catchments LUC (left) and LUT (right) during the study period. The arrows on the left and right of B), D) and F) mark the completion of harvesting and planting operations, respectively.

Variación temporal de la contribución relativa (A y B), la magnitud total de la contribución (C y D) y la carga acumulada de sedimentos (E y F) de las tres fuentes potenciales a las muestras integradas en el tiempo colectadas en las salidas de las cuencas LUC (izquierda) y LUT (derecha) durante el estudio. Las flechas a la izquierda y derecha en B), D) y F) marcan el término de las operaciones de cosecha y reforestación, respectivamente. 
the sediment output from the catchment. The contribution from the stream channel was reduced to $\sim 2 \%$ during a prolonged 7-month period extending from 24.11.2010 to 20.06.2011. However, after 20.06.2011, the importance of the channel as a sediment source was progressively restored to pre-harvest conditions. There is some evidence of the impact of replanting activity during this period, with increased contributions from the catchment surface and forest roads, which are likely to have been disturbed by this activity.

The magnitude of source contributions. Figures 4C and D provide information on the temporal variation of the absolute magnitude of the sediment contributions from the three sources to sediment output during the study period. The results for LUC (figure 4C) emphasize the importance of stream channels as the primary source of sediment exported from the catchment. This can be seen as indicative of sediment mobilization and delivery from the study area under essentially natural or undisturbed conditions. The results for LUT (figure 4D) highlight the seriously increased contribution from forest roads and the catchment surface after clearcutting, with these enhanced contributions continuing until the completion of the forest planting. In addition, the sizeable increase in the contribution of sediment from channel sources during the first, third and fourth observation periods following clearcutting (figure 4D) may reflect channel disturbances by harvesting activities, and increased winter storm discharges passing down the channels.

Figures $4 \mathrm{E}$ and $\mathrm{F}$ provide a useful summary of the changes in sediment output from LUT caused by forest harvesting and replanting operations. Overall, considering the entire study period, forest operations caused the total sediment output from LUT $\left(3160 \mathrm{~kg} \mathrm{ha}^{-1}\right)$ to be double than that from LUC $\left(1650 \mathrm{~kg} \mathrm{ha}^{-1}\right)$. This increase is coupled with major changes in the amounts of sediment contributed by the different sources. Under 'natural' conditions stream channels are the major sediment source, contributing $\sim 1390 \mathrm{~kg} \mathrm{ha}^{-1}$ during the study period (figure 4E), which represents $c a$. $84 \%$ of the of total sediment export. Forest harvesting in LUT caused the contributions from catchment slopes and forest roads to increase markedly, with both sources contributing ca. 25\% (i.e., 835 and $795 \mathrm{~kg} \mathrm{ha}^{-1}$, respectively) of the total sediment output in this catchment (figure 4F). However, the total contribution from channel sources for LUT during the study period $\left(1530 \mathrm{~kg} \mathrm{ha}^{-1}\right)$ remains similar to that from LUC (1390 kg ha $^{-1}$, figures $4 \mathrm{E}$ and F).

\section{DISCUSSION}

Catchment disturbances and impacts on runoff and sediment yield. The calibration period of common monitoring of the two catchments prior to the disturbance of LUT was limited to six months. The short calibration period and the fact that it did not include the season characterized by intense rainfall must be seen as a limitation of the study. However, it did include several events with substantial rainfall (figures 2A and B). The available data confirmed the essentially similar sediment response of the two catchments during the calibration period (figures 2E, F and $3 \mathrm{~B}$ ). The extension of the monitoring to include a period when LUT could be expected to have largely recovered from the disturbance caused by forest harvesting and when the specific sediment yields of the two catchments were again very similar provided further confirmation of the similarity of the response of the two catchments.

There were no detectable runoff increases in LUT after clearcutting (see figure 3A). This was somehow unexpected, since many paired catchment investigations have reported runoff increases after forest harvesting (Brown et al. 2005). However, limited changes or delayed runoff increases had also been reported by other paired catchment studies (David et al. 1994), and this behavior might confirm the suggestion of McDonnell et al. (2018) that "factors influencing the control variables on sustained annual water yield in forested headwaters are not well understood" when calling for better consideration of underground water storage.

The sediment output from LUT (figure 2F) provides clear evidence of increase after forest harvesting, when compared to that from LUC (figure 2E). Such behavior is well documented globally (Gayoso 2015). As clearcutting did not generate increases in runoff, the increase in the sediment loads in LUT was due to increases in suspended sediment concentrations, which were higher during the 4.5-month period immediately after harvesting (mean 305 $\mathrm{mg} \mathrm{l}^{-1}$, range 11-1638 $\mathrm{mg} \mathrm{l}^{-1}$ ) as compared with the control period (mean $50 \mathrm{mg} \mathrm{l}^{-1}$, range 14-104 $\mathrm{mg} \mathrm{l}^{-1}$ ). Comparing a 4.5-month observation period immediately after harvesting with a similar 4.5-month for the subsequent year, sediment output from LUT was three times higher than that from LUC, and the increase was reduced to a ca. 2-fold for the latter period. This fact is relevant when examining the long-term effect of harvesting on sediment movement. The reduction in the magnitude of the increase in sediment output from LUT, when compared to LUC, during the second wet season (i.e., one year after harvest) reflects some degree of stabilization of the catchment sediment source areas following logging. However, it is also seen as demonstrating delayed export of sediment, possibly held in storage, during the subsequent rainy season. During the two observation periods following the completion of replanting (11.10.2011 to 12.12.2011, table 2), the total sediment yields from LUC and LUT were similar, a fact that may reflect the limited rainfall $(142 \mathrm{~mm})$ during these periods although does not exclude the possibility of a delayed increase in the sediment yield from LUT during rainy periods, as also observed after logging.

The cumulative daily sediment load of both catchments (figure 3B) emphasizes the short-lived nature of the increase in sediment yield associated with the wet season 
following forest harvesting and the return to a similar response from both catchments by the time replanting was completed.

The discriminatory power of the fingerprint properties included in the study. The conservative nature of the individual fingerprint properties was tested using the 'range test'. Potassium-40 and ${ }^{226} \mathrm{Ra}$, which constitute intrinsic properties of the soil, failed this test, and were therefore not included in the subsequent statistical tests for identifying the optimum composite fingerprints. The inclusion of SOM confirms the ability of organic matter content to discriminate among material from catchment surface, forest road and river channel sources as reported by Ritchie et al. (2007).

Source contributions. Considering the pre-logging period, the forest roads represent a minor (less than $10 \%$ of the sediment output), nevertheless significant sediment source in both catchments. Relative source contributions from LUC remain constant during the rest of the study period, although roads assume higher importance during the wet seasons of both 2010 and 2011 when the road surfaces are likely to be subject to increased surface runoff and erosion. The contribution from roads also increases during the summer of 2010-2011, suggesting that the heavy rainfall that occurred during the winter of 2010 may have increased the importance of this sediment source during the subsequent summer by, for example, increasing instability of cut slopes and activating rills and small gullies. These effects were probably also enhanced by the increased use of forest roads in LUC during these periods in association with the harvesting activity in adjacent catchments.

These changes are highly consistent with the expected impact of clearcutting in disturbing both the catchment surface and forest roads and thereby increasing their susceptibility to erosion (Gayoso 2015). However, Luce and Black (1999) emphasize the importance of roads as a primary source of the sediment yield from forested catchments, and the $25 \%$ contribution of forest roads to the sediment yield from LUT after harvesting could be seen as low. It was considerably lower than that reported by Grace (2002), who found relative contributions from roads of ca. $90 \%$. Nevertheless, Rachels et al. (2020) found that the primary source of suspended sediment in pre and postharvesting conditions was streambank sediment.

In this study, the fingerprint properties of source material samples collected from stream channels differed from those collected from forest roads and catchment surfaces. However, Bravo-Linares et al. (2018) working in the LUC catchment used a compound-specific stable isotope technique to discriminate sediment sources. They found that 74-98 \% of the sediments in stream channels originated from unpaved roads. This might indicate that forest roads provide sediment to the stream during the entire plantation rotation, which is partially stored along channels thus showing a different signature to that associated with roads.
From a management perspective, information of the absolute magnitude of sediment contributions from the three sources to sediment output is much more relevant than that for the relative contributions of the three sources, since any sediment control or management strategy must aim at reducing the amounts of sediment transported downstream and focusing on the source or sources contributing most sediment.

The fact that the total contribution from channel sources for LUT during the study period remained like that from LUC, suggests that this catchment disturbance did not seriously change the amount of sediment contributed by channels. In this context, the results from the present study indicate that catchment slopes and forest roads represent important additional sources that are activated by the disturbance associated with forest harvesting and suggest that any management action should focus on these potential sources if the increased output of fine sediment from recently harvested areas in the study region is to be reduced. Further consideration when implementing management practices must, however, take account of the magnitude of sediment loads and source contributions from the study catchments. Overall, the fine sediment output from LUC, which can be seen as representing 'natural' conditions (estimated in the order of $750 \mathrm{~kg} \mathrm{ha}^{-1} \mathrm{y}^{-1}$ ) is relatively low by world standards (Bathurst and Iroumé 2014) and doubtlessly reflects the dense vegetation cover associated with forested catchments in the study area. However, aquatic ecosystems accustomed to relatively low sediment yields can prove highly sensitive to additional inputs of fine sediment to the stream network (Nor Zaiha et al. 2015). In this context a doubling of the fine sediment input caused by increased sediment contributions from the catchment surface and forest roads and an even higher increase (e.g., trebling) from these sources immediately following clearcutting, could have a significant impact on aquatic habitats. The adoption of proved best management practices, which can substantially reduce the connectivity among the catchment surface, roads, and the stream network, will reduce sediment mobilization and sediment concentrations (Schuller et al. 2010, Gayoso 2015, Cristan et al. 2016). Downstream transmission of increased sediment loads will clearly be influenced by the dilution of such contributions by inputs from undisturbed catchments. In these circumstances careful planning of the timing and location of forest harvesting activity could play an important role in reducing their downstream impacts.

\section{CONCLUSIONS}

This study, undertaken within a paired catchment investigation of forest harvesting impacts in an area of plantation forestry in southern Chile, has demonstrated the potential of sediment source fingerprinting techniques to provide information on the provenance and the relative 
and absolute contribution of different sediment source types to the sediment output from a catchment. The information on sediment source obtained is seen as adding an additional dimension to traditional catchment experiments that can inform better both understanding of the sediment dynamics of the catchment investigated and the adoption of sediment control strategies to be applied within the catchment during forestry operations.

During the entire study period the total specific sediment yield $\left(\mathrm{kg} \mathrm{ha}^{-1}\right)$ from the catchment disturbed by forestry operations approximately doubled that from the control catchment. Most of this difference is accounted for by the increase in sediment output that occurred during the first 4.5 rainy months after harvesting. The effects of forest harvesting in increasing sediment yield were coupled with a major shift in the importance of the three key sediment sources in the catchment. Prior to harvesting, the dominant sediment source in the two catchments was stream channels, and source contributions from the control catchment remained relatively constant during the remainder of the study period. However, clearcutting operations in the disturbed catchment caused substantial changes in the contribution of sediment sources. The total contribution of the stream channel showed little change, although the contribution from both the catchment surface and forest roads significantly increased.

These findings emphasize that any attempt to reduce the increase in sediment yield associated with forest harvesting operations needs to target both catchment slopes and forest roads. The adoption of best management practices could reduce sediment mobilization and transfer from catchment slopes to streams. Reduction of sediment mobilization from forest roads is likely to require improved road construction techniques and reduction of connectivity between road surfaces and cut slopes and stream channels. Careful attention to the timing of forest harvesting operations, so that the catchment has a larger time to recover prior to the wet season, clearly also offers scope for reducing sediment mobilization during the early stages of the post-harvest period.

\section{ACKNOWLEDGEMENTS}

The research was supported by the Chilean Government through FONDECYT Project 1090574 and by the Gobierno Regional de Los Ríos and DID-UACh, Chile. Support was also provided by FAO/IAEA through CRP D1.20.11 (Contract CHI-15531 and Technical Contract 15478) and the RLA 05/051 Project. Special thanks to the Forest Research Center, Universidad Austral de Chile, for providing the study sites, and to Prof. Anton Huber for his support for the hydrological monitoring program and assistance with the processing of rainfall and flow data. Finally, we acknowledge the suggestions by two anonymous reviewers which significantly helped to improve our manuscript.

\section{REFERENCES}

Appleby PG, F Oldfield. 1978. The calculation of lead-210 dates assuming a constant rate of supply of unsupported ${ }^{210} \mathrm{~Pb}$ to the sediment. Catena 5: 1-8. DOI: $\underline{10.1016 / \mathrm{S} 0341-}$ $\underline{8162(78) 80002-2}$

Bathurst JC, A Iroumé. 2014. Quantitative generalizations for catchment sediment yield following forest logging. Water Resources Research 50. DOI: 10.1002/2014WR015711.

Buttle JM. 2011. The Effects of Forest Harvesting on Forest Hydrology and Biogeochemistry. In Levia DF，D Carlyle-Moses, T Tanaka eds. Forest Hydrology and Biogeochemistry: Synthesis of Past Research and Future Directions. Ecological Studies 216. Springer Science+Business Media. p. 659677. B.V. DOI: $10.1007 / 978-94-007-1363-533$.

Bravo-Linares C, P Schuller, A Castillo, L Ovando-Fuentealba, E Muñoz-Arcos, O Alarcón, S de los Santos-Villalobos, R Cardoso, M Muniz, R Meigikos dos Anjos, R Bustamante-Ortega, G Dercon. 2018. First use of a compound-specific stable isotope (CSSI) technique to trace sediment transport in upland forest catchments of Chile. Science of the Total Environment 618: 1114-1124. DOI: 10.1016/j.scitotenv.2017.09.163

Brown AE, L Zhang, TA McMahon, AW Western, RA Vertessy. 2005. A review of paired catchment studies for determining changes in water yield resulting from alterations in vegetation. Journal of Hydrology 310: 28-61. DOI: 10.1016/j. jhydrol.2004.12.010

Collins AL, S Pulley S, IDL Foster, A Gellis, P Porto, AJ Horowitz. 2017. Sediment source fingerprinting as an aid to catchment management: A review of the current state of knowledge and a methodological decision-tree for endusers. Journal of Environmental Management 194: 86-108. DOI: 10.1016/j.jenvman.2016.09.075

Cristan R, WM Aust, MC Bolding, SM Barrett, JF Munsell, E Schilling. 2016. Effectiveness of forestry best management practices in the United States: Literature review. Forest Ecology and Management 360:133-151. DOI: 10.1016/j. foreco.2015.10.025

David JS, MO Henriques, TS David, J Tom, DC Ledger. 1994. Clearcutting effects on streamflow in coppiced Eucalyptus globulus stands in Portugal. Journal of Hydrology 162: 143-154.

Douglas GB, M Palmer, G Caitcheon. 2003. The provenance of sediments in Moreton Bay, Australia: a synthesis of major, trace element and $\mathrm{Sr}-\mathrm{Nd}-\mathrm{Pb}$ isotopic geochemistry, modelling and landscape analysis. Hydrobiologia 494:145-52. DOI: $10.1007 / 978-94-017-3366-3 \quad 20$

Gayoso J. 2015. Water quality and limitations to forest clearcutting: a recurrent discussion. In Niklitschek $\mathrm{M}$ ed. Tamaño de la tala rasa en plantaciones forestales: efectos y regulación, $1^{\text {a }}$ Edición, Editorial Universitaria. pp. 63-83.

Grace JM, III. 2002. Control of sediment export from the forest road prism. Transactions of the ASAE 45(4): 1127-1132.

He Q, DE Walling. 1996. Interpreting particle size effects in the adsorption of ${ }^{137} \mathrm{Cs}$ and unsupported ${ }^{210} \mathrm{~Pb}$ by mineral soils and sediments. J. Environ. Radioact. 30: 117-137. DOI: $\underline{10.1016 / 0265-931 X(96) 89275-7}$

Huber A, A Iroumé, C Mohr, C Frêne. 2010. Effect of Pinus radiata and Eucalyptus globulus plantations on water resource in the Coastal Range of Biobio region, Chile. Bosque 31: 219-230. DOI: $10.4067 /$ S0717-92002010000300006 
Iroumé A., O Mayen, A Huber. 2006. Runoff and peak flow responses to timber harvest and forest age in southern Chile. Hydrological Processes 20: 37-50. DOI: 10.1002/hyp.5897

Luce CH, TA Black. 1999. Sediment production from forest roads in western Oregon. Water Resources Research 35(8): 2561-2570. DOI: 10.1029/1999WR900135

Matisoff G, EC Bonniwell, PJ Whiting. 2002. Radionuclides as indicators of sediment transport in agricultural watersheds that drain to Lake Erie. Journal of Environmental Quality 31: 62-72. DOI: $10.2134 /$ jeq2002.6200

McDonnell J J, J Evaristo, KD Bladon, J Buttle, IF Creed, SF Dymond, G Grant, A Iroumé, CR Jackson, JA Jones, T Maness, KJ McGuire, DF Scott, C Segura, RC Sidle, C Tague. 2018. Water sustainability and watershed storage. Nature Sustainability 1: 378-379. DOI: 10.1038/s41893-018-0099-8

Nor Zaiha A, MS Mohd Ismid Salmiati, MS Shahrul Azri. 2015. Effects of logging activities on ecological water quality indicators in the Berasau River, Johor, Malaysia. Environmental Monitoring and Assessment 187: 493. DOI: 10.1007/s10661-015-4715-Z

Rachels AA, KD Bladon, S Bywater-Reyes, JA Hatten. 2020. Quantifying effects of forest harvesting on sources of suspended sediment to an Oregon Coast Range headwater stream. Forest Ecology and Management 466: 118-123. DOI: $\underline{10.1016 / \text { j.foreco.2020.118123. }}$.

Ritchie JC, GW McCarty, ER Venteris, TC Kaspar. 2007. Soil and soil organic carbon redistribution on the landscape. Geomorphology 89: 163-171. DOI: 10.1016/j.geomorph.2006.07.021
Schuller P, A Ellies, G Kirchner. 1997. Vertical migration of fallout ${ }^{137} \mathrm{Cs}$ in agricultural soils from southern Chile. Science of the Total Environment 193: 197-205. DOI: 10.1016/ $\underline{\mathrm{S} 0048-9697(96) 05338-7}$

Schuller P, DE Walling, A Iroumé, A Castillo 2010. Use of ${ }^{7} \mathrm{Be}$ measurements to study the effectiveness of woody trash barriers in reducing soil erosion and sediment delivery to streams after forest clearcutting. Soil Tillage Res. 110: 143153. DOI: $\underline{10.1016 / j . s t i l l .2010 .07 .004}$

Schuller P, DE Walling, A Iroumé, C Quilodrán, A Castillo, A Navas. 2013. Using ${ }^{137} \mathrm{Cs}$ and ${ }^{210} \mathrm{~Pb}_{\mathrm{ex}}$ and other sediment source fingerprints to document suspended sediment sources in small forested catchments in south-central Chile. Journal of Environmental Radioactivity 124: 147-159. DOI: 10.1016/j.jenvrad.2013.05.002

Sidle RC, S Sasaki, M Otsuki, S Noguchi, AR Nik. 2004. Sediment pathways in a tropical forest: effects of logging roads and skid trails. Hydrological Processes 18: 703-720. DOI: 10.1002/hyp.1364

Walling DE. 2005. Tracing suspended sediment sources in catchments and river systems. Science of the Total Environment 344: 150-184. DOI: 10.1016/j.scitotenv.2005.02.011

Walling DE. 2013. The evolution of sediment source fingerprinting investigations in fluvial systems. Journal of Soils and Sediment 13: 1658-1675. DOI: 10.1007/s11368-0130767-2.

Walling DE, AL Collins. 2000. Integrated Assessment of Catchment Sediment Budgets: A Technical Manual. University of Exeter.

Recibido: $30 / 11 / 20$

Aceptado: 20/06/21 